\title{
Analisis Merkuri (Hg) dan Arsen (As) di Sedimen Sungai Ranoyapo Kecamatan Amurang Sulawesi Utara
}

\author{
Melin T. Kitonga ${ }^{*}$, Jemmy Abidjulua, Harry. S. J. Koleangana \\ aJurusan Kimia, FMIPA, Unsrat, Manado
}

\section{KATA KUNCI}

Merkuri

Arsen

sedimen

\begin{tabular}{l}
$\overline{\text { K E Y W O R D S }}$ \\
\hline Mercury \\
Arsenic \\
Sediment
\end{tabular}

\begin{tabular}{l} 
A B S T R A K \\
Penelitian ini bertujuan untuk mengukur konsentrasi merkuri dan \\
arsen di sedimen Sungai Ranoyapo. Pengukuran konsentrasi total merkuri \\
menggunakan Cold Vapor-Atomic Absorption Spectrometry (CV-AAS) \\
sedangkan pengukuran konsentrasi total arsen menggunakan Atomic \\
Absorption Spectrometry (AAS). Hasil yang diperoleh menunjukkan \\
konsentrasi total merkuri di sedimen sungai yang diambil dari Desa \\
Lompad, Desa Picuan, Desa karimbow I, Desa Karimbow II dan muara \\
Sungai Ranoyapo berturut-turut yaitu 0,05 ppm, 0,05 ppm, 1,3 ppm, 0,18 \\
ppm dan 0,05 ppm. Konsentrasi total arsen di sedimen sungai yang \\
diambil dari Desa Lompad, Desa Picuan, Desa Karimbow I, Desa \\
Karimbow II dan muara Sungai Ranoyapo berturut-turut yaitu 3 ppm, 2 \\
ppm, 100 ppm, 2 ppm dan 1 ppm. Konsentrasi total merkuri dan arsen \\
tertinggi adalah di Desa Karimbow I yang merupakan daerah \\
pertambangan emas rakyat. \\
\hline A B S T A C T \\
This research was aimed to measure the concentrations of mercury \\
and arsenic in the sediments of Ranoyapo River. The concentration of \\
mercury was measured as the total of mercury (THg) using cold vapor- \\
atomic absorption spectrometry (CV-AAS) while the total of arsenic (TAs) \\
was measured using the atomic absorption spectrometry (AAS). The result \\
showed that total concentration of mercury in the river's sediment taken \\
from the area of Lompad Village, Picuan Village, Karimbow I Village, \\
Karimbow II Village and the mouth of Ranoyapo River were 0.05; 0.05; \\
1.3; 0.18 and 0.05 ppm respectively. The total concentration of arsenic in \\
the river's sediment taken from the area of Lompad Village, Picuan Village, \\
Karimbow I Village, Karimbow II Village and the mouth of Ranoyapo River \\
were 3; $2 ; 100 ; 2$ and 1 ppm. The highest total concentration of mercury \\
and arsenic were in the river's sediment taken from the area of Karimbow \\
I Village which was an area of artisanal gold mining.
\end{tabular}

\section{Pendahuluan \\ Dalam kegiatan pertambangan emas rakyat (artisanal mining), salah satu proses untuk mendapatkan emas adalah proses amalgamasi, di mana proses amalgamasi adalah proses percampuran antara emas dan merkuri (Hg). Teknik amalgamasi dilakukan dengan cara mencampur batuan yang mengandung logam emas dan merkuri dengan menggunakan tromol (Sualang, 2001). Dalam kegiatan tersebut dibutuhkan aliran air untuk memisahkan batuan halus dan amalgam (campuran}

merkuri dan emas) yang dialirkan ke kolam penampungan limbah (tailling) (Lingkubi, 2004).

Umumnya merkuri masuk ke perairan sungai dalam bentuk $\mathrm{Hg}$ unsur $(\mathrm{Hg})$ dengan densitas yang tinggi. Merkuri ini akan tenggelam ke dasar perairan atau terakumulasi di sedimen pada kedalaman 5-15 $\mathrm{cm}$ di bawah permukaan sedimen. Merkuri unsur tersebut dapat berubah menjadi merkuri organik oleh aktivitas bakteri, yaitu menjadi metil merkuri $\left(\mathrm{CH}_{3} \mathrm{Hg}\right)$, yang memiliki sifat racun dan daya ikat yang sangat kuat serta kelarutannya yang tinggi terutama dalam tubuh hewan air misalnya ikan (Budiono, 2003).

*Corresponding author: Jurusan Kimia FMIPA UNSRAT, Jl. Kampus Unsrat, Manado, Indonesia 95115; Email address: melinkitong@yahoo.com Published by FMIPA UNSRAT (2012) 
Pertambangan rakyat yang ada di Sulawesi Utara, khususnya Minahasa Selatan, pada umumnya kurang memerhatikan faktor pengelolaan lingkungan baik dalam pengelolaan limbah yang dihasilkan maupun bahan berbahaya yang digunakan. Salah satu wilayah pengolahan emas yang menggunakan teknik amalgamasi adalah di Daerah Aliran Sungai (DAS) Ranoyapo di Kecamatan Amurang. Berdasarkan informasi tersebut maka perlu dilakukan analisis kandungan logam berat seperti merkuri dan arsen yang terkandung di sedimen Sungai Ranoyapo.

\section{Metode}

\subsection{Alat dan Bahan}

Alat utama yang digunakan dalam penelitian ini Atomic Absorption Spektrometry (AAS), Cold VaporAtomic Absorption Spektrrometry (CV-AAS).

Bahan yang digunakan adalah sampel sedimen, campuran asam nitrat-asam perklorat ( $\left.\mathrm{HNO}_{3}-\mathrm{HClO}_{4}\right)$ (1:1), asam sulfat $\left(\mathrm{H}_{2} \mathrm{SO}_{4}\right)$, air distilasi, asam klorida $(\mathrm{HCl})$, larutan timah(II) klorida $\left(\mathrm{SnCl}_{2}\right) 10 \%$, larutan standar merkuri (Hg), larutan standar arsen (As).

\subsection{Teknik Pengambilan Sampel}

Teknik pengambilan sampel sedimen dilakukan menurut petunjuk Japan Public Health Association (JPHA) (Anonim, 2001). Sedimen diambil dengan menggunakan pipa paralon dan diambil sedimen yang berada pada $10-15 \mathrm{~cm}$ dari permukaan sedimen.
Sampel dipisahkan dari kerikil, potongan binatang, tumbuhan dan objek lain.

Untuk satu lokasi terdapat 5 titik tempat pengambilan sampel sedimen. Sampel dari masingmasing titik tersebut dicampur untuk mendapatkan 1 komposit sampel. Sampel kemudian disaring dengan menggunakan ayakan dengan ukuran 2 mesh. Sampel dimasukkan ke dalam botol, disegel dan dimasukkan ke dalam kotak pendingin (coolen box) bersama dengan es batu selama transportasi. Sampel disimpan dalam ruang beku (freezer) sebelum dilakukan pengukuran. Hal ini dilakukan untuk mencegah aktivitas mikroba dalam sedimen. Kemudian sampel di analisis di Water Laboratory Nusantara (WLN).

\section{Hasil dan Pembahasan}

\subsection{Konsentrasi Merkuri}

Hasil analisis konsentrasi merkuri di Sungai Ranoyapo pada 5 lokasi pengambilan sampel disajikan pada Tabel 1 di bawah ini.

Dari kelima tempat pengambilan sampel diperoleh kandungan merkuri tertinggi adalah pada sampel sedimen di Desa Karimbow I yaitu sebesar 1,3 ppm berat kering dan yang terendah adalah pada sampel sedimen di Desa Lompad, Desa Picuan dan muara Sungai Ranoyapo yaitu sebesar 0,05 ppm berat kering.

Tabel 1 - Konsentrasi total Hg (THg) dalam sampel sedimen di sungai Ranoyapo.

\begin{tabular}{|l|c|}
\hline \multicolumn{1}{|c|}{ Lokasi } & Konsentrasi (mg/kg) \\
\hline Desa Lompad (Titik I) & 0,05 \\
\hline Desa Picuan (Titik II) & 0,05 \\
\hline Desa Karimbow I/Lokasi Tambang (Titik III) & 1,3 \\
\hline Desa Karimbow II (titik IV) & 0,18 \\
\hline Muara Sungai Ranoyapo (Titik V) & 0,05 \\
\hline
\end{tabular}

Hasil penelitian ini menunjukkan bahwa jarak dari lokasi pertambangan menentukan tingkat konsentrasi merkuri yang terakumulasi dalam sedimen, di mana semakin dekat jarak dari lokasi penambangan maka semakin tinggi pula konsentrasi merkuri dibandingkan dengan lokasi yang berada jauh dari lokasi pertambangan.

Dari data tersebut dapat diduga bahwa penambangan emas rakyat yang menggunakan teknik amalgamasi dalam pengolahannya telah menyebabkan pencemaran sungai di sekitarnya. Meskipun standar baku mutu untuk sedimen sungai belum ditentukan, namun di Desa Karimbow I, konsentrasi merkuri hampir mencapai $2 \mathrm{ppm}$, di mana menurut Veiga dan Meech (1995) sedimen yang memiliki konsentrasi merkuri di atas $2 \mathrm{ppm}$ berarti sudah terkontaminasi dengan merkuri yang berasal dari kegiatan pertambangan yang ada di sekitar titik pengambilan sampel. Diperkirakan merkuri yang ada merupakan imbasan dari tromol yang digunakan pada proses pengolahan emas yang menggunakan merkuri.
Pengolahan emas dengan teknik amalgamasi telah menyebabkan kontaminasi sedimen sungai. Sedimen yang telah terkontaminasi oleh merkuri berpotensi menimbulkan dampak lingkungan yang negatif dan berbahaya bagi masyarakat yang tinggal di sekitar sungai tersebut. Kontaminasi sedimen sungai oleh merkuri di sekitar daerah tambang emas rakyat berhubungan langsung dengan proses pengolahan emas dengan cara amalgamasi dimana mineral sulfida logam, bersama dengan logam merkuri terbuang sebagai campuran halus material tailing.

Di daerah yang dekat dengan lokasi pertambangan, merkuri di sedimen sebagian besar (80-90\%) berbentuk merkuri unsur ( $\left.\mathrm{Hg}^{0}\right)$. Di ekosistem perairan merkuri unsur mengalami penurunan konsentrasi yang sangat lambat. Hal ini disebabkan oleh lemahnya merkuri yang larut dalam air, terlebih lagi akumulasinya di bagian dasar sungai seringkali dihubungkan dengan karakteristik hidrologis sungai tersebut. Jika telah menutupi 
seluruh sedimen, merkuri unsur akan bertahan dalam waktu yang lama (Putra, 2011).

Tingginya kadar merkuri di Desa Karimbow I di duga memiliki korelasi positif dengan keberadaan penambangan emas rakyat yang menggunakan teknik amalgamasi. Hal tersebut sesuai dengan pendapat Setiabudi (2005), bahwa penambangan emas rakyat yang menggunakan teknik amalgamasi diduga menyebabkan kontaminasi merkuri di daerah sekitarnya. Dari data di atas juga menunjukkan bahwa di lokasi ini kandungan merkuri dalam sedimen sudah cukup tinggi yang disebabkan oleh pengolahan emas yang menggunakan merkuri sudah berlangsung cukup lama di sekitar sungai.

Sedimen di daerah yang jauh dari lokasi penambangan emas, sedimennya mengandung konsentrasi merkuri yang belum melampaui nilai batas kontaminasi. Diperkirakan merkuri yang terbawa oleh sedimen dari hulu (daerah pertambangan) dapat mengakumulasi daerah muara. Hal ini disebabkan merkuri yang terendap bersama sedimen di sepanjang sungai dapat membentuk "hot spot" kontaminasi antara estuari dan daerah kegiatan pertambangan, terutama pada aliran sungai yang tidak terlalu deras (Putra, 2011). Proses ini akan terbawa terus sepanjang waktu dan menyebabkan terjadinya peningkatan konsentrasi di daerah estuari. Hal ini dapat dilihat pada sampel yang diambil di Desa Karimbow II.

Di Desa karimbow II konsentrasi merkuri mencapai 0,18 ppm yang memperlihatkan konsentrasi tersebut di atas konsentrasi merkuri alami di Desa Lompat, desa Picuan dan muara sungai Ranoyapo. Kondisi ini menunjukan bahwa konsentrasi merkuri dalam sedimen akan mengalami penurunan apabila jaraknya semakin jauh dari daerah pertambangan. Kemampuan mobilitas merkuri yang rendah menyebabkan belum banyak merkuri yang mencapai bagian hilirnya. Sedangkan hal yang memungkinkan membantu penyebaran merkuri adalah aliran air yang terus menerus.

\subsection{Konsentrasi Arsen (As)}

Hasil analisis konsentrasi arsen di Sungai Ranoyapo pada 5 lokasi pengambilan sampel disajikan pada Tabel 2 di bawah ini.

Tabel 2 - Konsentrasi total As (TAs) dalam sampel sedimen di sungai Ranoyapo.

\begin{tabular}{|l|c|}
\hline \multicolumn{1}{|c|}{ Lokasi } & Konsentrasi (mg/kg) \\
\hline Desa Lompad (Titik I) & 3 \\
\hline Desa Picuan (Titik II) & 2 \\
\hline Desa Karimbow I/Lokasi Tambang (Titik III) & 2 \\
\hline Desa Karimbow II (titik IV) & 1 \\
\hline Muara Sungai Ranoyapo (Titik V) & 2 \\
\hline
\end{tabular}

Dari kelima tempat pengambilan sampel didapat bahwa kandungan arsen tertinggi adalah pada sampel sedimen adalah di Desa karimbow I yaitu sebesar 100 ppm berat kering dan terendah adalah pada sampel sedimen di muara Sungai Ranoyapo yaitu sebesar $1 \mathrm{ppm}$ berat kering.

Konsentrasi arsen di Desa Lompad diduga berasal dari pelapukan batuan alami karena di sekitar tempat pengambilan sampel tidak ditemukan adanya kegiatan pertambangan. Hasil tersebut menunjukkan bahwa konsentrasi alami arsen dalam sedimen sungai berkisar antara 1-50 ppm. Konsentrasi arsen menurun dengan semakin jauhnya jarak dari daerah pertambangan. Konsentrasi arsen yang ada di sedimen dua kali lebih tinggi dibandingkan konsentrasi arsen di tanah. Hal ini disebabkan karena pelapukan batu yang lebih tinggi dan masukan dari sumber-sumber antropogenik sehingga kandungan arsen lebih tinggi di sedimen sungai dari pada di tanah (Pattel et al., 2005).

Arsen yang didapat di Desa Lompad, Desa Picuan, Desa Karimbou II dan di muara Sungai Ranoyapo juga diperkirakan masih dalam kontaminasi alami karena secara alami kandungan arsen dalam sedimen biasanya di bawah 10 ppm berat kering (Sukar, 2003). Kontaminasi arsen merupakan hasil dari proses alami geologi dan juga merupakan buangan dari manusia yang merupakan hasil dari kegiatan pertambangan, peternakan, industri dan pertanian (Pettel, et al., 2005).

Tingginya kandungan arsen di Desa Karimbow 1 terjadi akibat adanya mineralisasi. Pengolahan bijih emas mengandung arsen dengan membuang tailling pada lingkungan sekitarnya akan berpotensi mempertinggi kandungan arsen pada aliran sungai (Anonim, 2006). Tingginya kandungan arsen di sedimen juga diakibatkan oleh adanya kegiatan pertambangan. Menurut Indarwati, et al., (2007) di daerah pertambangan biasanya memiliki kadar $\mathrm{pH}$ yang rendah. Di mana pada $\mathrm{pH}<5,8$ arsen berada dalam bentuk $\mathrm{As}^{+5}$ yang bersifat kurang larut dalam air.

\section{Kesimpulan}

Konsentrasi total merkuri di Desa Lompad, Desa Picuan, Desa karimbow I, Desa Karimbow II dan muara Sungai Ranoyapo berturut-turut yaitu 0,05 ppm, 0,05 ppm, 1,3 ppm, 0,18 ppm dan 0,05 ppm. Konsentrasi total di Desa Lompad, Desa Picuan, Desa Karimbow I, Desa Karimbow II dan muara Sungai Ranoyapo berturut-turut yaitu 3 ppm, 2 ppm, 100 ppm, 2 ppm dan 1 ppm. 
seminar Dampak Penggunaan Merkuri Dalam Penambangan Emas Terhadap Kesehatan Manusia. 2004.

\section{Daftar Pustaka}

Anonim. Preventive Measures Against Environment Mercury Pollution and Its Health Effects. Japan Public Health Association. Japan. 112 pp. 2001.

Anonim. Laporan Pendataan Penyebaran Unsur Merkuri pada Wilayah Pertambangan Selogiri, Kabupaten Wonogiri, Provinsi Jawa Tengah. Departemen Energi dan Sumber Daya Mineral. Badan Geologi Pusat Sumber Daya Geologi. Bandung. 2006.

Budiono, A. Pengaruh Pencemaran Merkuri Terhadap Biota Air. Makalah Pengantar Sains. Program Pascasarjana (S3). IPB. 2003.

Halimah, S. Pencemaran Merkuri dan Strategi Penanganan Penambangan Emas Tanpa Izin di Pongkor Jawa Barat. Tesis, Universitas Indonesia, 2003.

Indarwati T. Maria, M.S. Mahendra, I W. Arthana. Analisis Kadar Logam Berat Air Sungai Sekonyer di Kabupaten Kotawaringin Barat Kalimantan Tengah. Ecotrophic. 2007, 2, 1-10.

Lingkubi, O. Upaya Pemerintahan Dalam Mengatasi Dampak Pencemaran Pertambangan Rakyat Di Kecamatan Dimembe. Makalah disampaikan pada
Putra, M. R. Y. K. Potensi Kontaminasi Merkuri di Lingkungan Perairan dan Manusia di Sungai Talawaan. Tesis, Universitas Sam Ratulangi, 2011.

Setiabudi, T. B. Penyebaran Merkuri Akibat Usaha Pertambangan Emas di Daerah Sangon, Kabupaten Kulon Projo, D. I Jogjakarta. Kolokium Hasil Lapangan. DIM. 2005.

Shrivas, K. S., Patel, K., Brandt, R., Jakubowski, N., Corns, W., Hoffmann, P. Arsenic Contamination in Water, Soil, Sediment and Rice of Central India. Environmental Geochemistry and Health. 2005, 27, 131-145.

Sualang, F. H. Kondisi, Permasalahan Pertambangan Emas Terhadap Lingkungan Hidup Di Propinsi Sulawesi Utara. Makalah disampaikan pada seminar sehari Dampak Penambangan Emas Dengan Menggunakan Merkuri Terhadap Kesehatan Manusia. Manado. 2001.

Sukar. Sumber dan Terjadinya Arsen di Lingkungan (Review). Jurnal Ekologi Kesehatan. 2003, 2, 232238.

Veiga, M. M. and Meech, J. A... HfEx-A Heuristic on Mercury pollution in the Amazone. Water, Air and Soil Pollution. 1995, 80, 123-132. 